\section{Carta Resposta: Queja por plagio de artículo}

Roberto Ariel Abeldaño ${ }^{2}$

Alicia Ruth Fernández ${ }^{2}$

${ }^{2}$ Facultad de Ciencias Médicas, Universidad Nacional de Córdoba. Córdoba Argentina.

Estimada Doctora, los autores Roberto Ariel Abeldaño y Alicia Ruth Fernández, del artículo "Salud mental en la comunidad en situaciones de desastre. Una revisión de los modelos de abordaje en la comunidad"', publicado con Doi: 10.1590/1413-81232015212.175020, en el año 2016 en la Revista Ciência \& Saúde Coletiva, nos dirigimos a usted y a los autores Cristian David Osorio Yepes y Victoria E. Díaz Facio Lince (en adelante: los autores Osorio y Díaz) ${ }^{2}$, en respuesta a su carta con asunto "Queja por plagio de artículo y solicitud de acciones correctivas".

En dicha carta, los autores Díaz y Osorio refieren que hubo un caso de plagio hacia el artículo titulado "Modelos de intervención psicosocial en situaciones de desastre por fenómeno natural" publicado por los autores Osorio y Díaz, disponible en la URL: http://aprendeenlinea.udea.edu.co/ revistas/index.php/psicologia/article/view/15481.

En dicha carta los autores detallan que se cometió plagio al utilizar en nuestro artículo, las ideas expresadas por ellos en su artículo. En respuesta a su planteo, nosotros declaramos que se trata de una omisión involuntaria y que no hubo mala fe, ni ninguna intención deliberada de dañar a los autores Osorio y Díaz.

Planteamos que no hubo mala fe, ni intención deliberada de dañar a los autores Osorio y Díaz, argumentando que el mismo fue citado con el número “37”, tal como se puede observar en la lista de referencias de nuestro artículo. Así también por tratarse de un artículo de revisión, es esperable que se utilicen las ideas de distintos autores cuyos artículos sean incluidos en los trabajos de revisión.

El archivo original en Word fue escaneado con software IThenticate (Licencia institucional) con fecha 09 de noviembre de 2018, y el análisis arrojó una coincidencia del 3\% con el artículo de Osorio y Díaz ${ }^{2}$.

A pesar de que el escaneo con un software detector de plagio de primera línea arroja una coincidencia mínima, hallamos razón en el planteo de los autores Osorio y Díaz, en el sentido de que la cita 37 debería ser extensiva a los demás pasajes que ellos señalan. Por esta omisión involuntaria ofrecemos nuestras disculpas pertinentes al caso a los autores Osorio y Díaz; y a la Editorial, puesto que no es nuestra intención actuar con mala fe, ni dañar la propiedad de los autores, ni el prestigio de la casa Editorial de la Revista.

En acuerdo con los argumentos de Osorio y Díaz, donde detallan que en pasajes específicos de la página 437 y 439 de nuestro artículo fue omitida la cita hacia su publicación; y en acuerdo con los análisis y las sugerencias del Comité Editorial de la revista, solicitamos las acciones correctivas del caso de acuerdo al detalle que se ofrece a continuación:

\section{En el artículo en Español:}

Donde dice:

Algunos se basan en enfoques de desarrollo humano, biológico-epidemiológico o comunitario $[\ldots]$

Debe hacerse extensiva la cita " 37 " y debe decir:

Algunos se basan en enfoques de desarrollo humano, biológico-epidemiológico o comuni$\operatorname{tario}^{37}[\ldots]$

Donde dice:

En general, pueden clasificarse los modelos de intervención entre los que están basados en el tiempo, intervenciones centradas en tipos de eventos específicos, las intervenciones que se realizan por niveles de acción y las intervenciones centradas en las personas.

Debe hacerse extensiva la cita " 37 " y debe decir:

Siguiendo a Osorio y Díaz, pueden clasificarse los modelos de intervención entre los que están basados en el tiempo, intervenciones centradas en tipos de eventos específicos, las intervenciones que se realizan por niveles de acción y las intervenciones centradas en las personas ${ }^{37}$.

Donde dice:

En este modelo, las intervenciones ponen énfasis en la cuestión temporal: antes, durante y después del desastre. Los intereses son prioritariamente puestos en las respuestas desde dos puntos de vista: las consecuencias de la población frente al desastre y las acciones que pueden realizar los profesionales con esa comunidad.

Debe hacerse extensiva la cita " 37 " y debe decir:

En este modelo, las intervenciones ponen énfasis en la cuestión temporal: antes, durante y después del desastre. Los intereses son prioritariamente puestos en las respuestas desde dos puntos de vista: las consecuencias de la población frente al desastre y las acciones que pueden realizar los profesionales con esa comunidad ${ }^{37}$.

Donde dice:

Es importante destacar que aunque en la experiencia internacional la mayoría de las intervenciones que se rescatan son realizadas desde una 
mirada emergentista (centrada en el evento); desde hace algunos años el modelo ha empezado a tener un enfoque transversal en el tiempo, donde los conceptos de integralidad, promoción, prevención y recuperación han tomado gran fuerza ${ }^{39}$.

Debe hacerse extensiva la cita " 37 ” y debe decir:

Es importante destacar que aunque en la experiencia internacional la mayoría de las intervenciones que se rescatan son realizadas desde una mirada emergentista (centrada en el evento); desde hace algunos años el modelo ha empezado a tener un enfoque transversal en el tiempo, donde los conceptos de integralidad, promoción, prevención y recuperación han tomado gran fuerza ${ }^{37,39}$.

Donde dice:

En este caso las intervenciones pasan de estar centradas en la supervivencia y la recuperación material a estar basadas en niveles integrados dependiendo de las necesidades de la población afectada y contemplando los distintos sectores de acción. Aquí cobra gran relevancia la capacidad de articular a la comunidad afectada y demás actores sociales a los procesos que llevan a cabo distintas instituciones, con el objetivo de resolver necesidades de distintos niveles en una situación de desastre. El Proyecto Esfera ${ }^{50}$, aunque su sede se encuentra en Ginebra, Suiza, representa una iniciativa internacional que dio los primeros pasos en implementar estrategias integrales en situaciones de desastre.

Debe hacerse extensiva la cita " 37 " y debe decir:

En este caso las intervenciones pasan de estar centradas en la supervivencia y la recuperación material a estar basadas en niveles integrados dependiendo de las necesidades de la población afectada y contemplando los distintos sectores de acción $^{37}$. Aquí cobra gran relevancia la capacidad de articular a la comunidad afectada y demás actores sociales a los procesos que llevan a cabo distintas instituciones, con el objetivo de resolver necesidades de distintos niveles en una situación de desastre. El Proyecto Esfera ${ }^{50}$, aunque su sede se encuentra en Ginebra, Suiza, representa una iniciativa internacional que dio los primeros pasos en implementar estrategias integrales en situaciones de desastre.

Donde dice:

Los modelos basados en este tipo de intervención buscan fuertemente el empoderamiento y la participación de la comunidad afectada, para que se integre a las actividades de ayuda. Aquí el foco está puesto en la potencialidad y no en el déficit. La concepción de salud mental tiene un componente comunitario en donde se busca integralidad en las acciones de promoción, prevención, atención y recuperación, a nivel familiar y comunitario en las poblaciones afectadas. Se puede mencionar al manual de apoyo y guía de procedimientos en salud mental desarrollado en Colombia ${ }^{51}$ como uno de los casos que se plantea bajo este modelo.

Debe hacerse extensiva la cita " 37 " y debe decir:

Siguiendo a Osorio y Díaz, los modelos basados en este tipo de intervención buscan fuertemente el empoderamiento y la participación de la comunidad afectada, para que se integre a las actividades de ayuda ${ }^{37}$. Aquí el foco está puesto en la potencialidad y no en el déficit. La concepción de salud mental tiene un componente comunitario en donde se busca integralidad en las acciones de promoción, prevención, atención y recuperación, a nivel familiar y comunitario en las poblaciones afectadas $^{37}$. Se puede mencionar al manual de apoyo y guía de procedimientos en salud mental desarrollado en Colombia ${ }^{51}$ como uno de los casos que se plantea bajo este modelo.

Donde dice:

Se incluyeron varias perspectivas para el abordaje de la salud mental comunitaria en esas situaciones: las intervenciones basadas en el tiempo, las que están centradas en un tipo de desastres específico, las intervenciones por niveles de acción o esferas y las centradas en las personas.

Debe hacerse extensiva la cita “37" y debe decir:

Se incluyeron varias perspectivas para el abordaje de la salud mental comunitaria en esas situaciones: las intervenciones basadas en el tiempo ${ }^{37}$, las que están centradas en un tipo de desastres específico $^{40-49}$, las intervenciones por niveles de acción o esferas y las centradas en las personas ${ }^{27}$.

Donde dice:

La mayoría de los documentos analizados están orientados a los profesionales intervinientes y $[\ldots]$

Debe hacerse extensiva la cita “37" y debe decir:

"La mayoría de los documentos analizados están orientados a los profesionales intervinientes" ${ }^{\prime 37} \mathrm{y}[\ldots]$

\section{En el artículo en Inglés:}

Donde dice:

There are models based on a human development approach, on a biological-epidemiological approach, and on a community approach [...]

Debe hacerse extensiva la cita "37" y debe decir:

There are models based on a human development approach, on a biological-epidemiological approach, and on a community approach ${ }^{37}[\ldots]$

Donde dice: 
Following Osorio and Diaz, intervention models may be classified in four groups: interventions based on time, interventions that are centered on specific types of events, interventions according to levels of action, and interventions centered on persons.

Debe hacerse extensiva la cita "37" y debe decir: Following Osorio and Diaz, intervention models may be classified in four groups: interventions based on time, interventions that are centered on specific types of events, interventions according to levels of action, and interventions centered on persons ${ }^{37}$.

Donde dice:

This model emphasizes the moment of intervention: before, during, and after the disaster. Responses prioritize two aspects: the consequences of disasters for the community and the actions that may be carried out by the professionals of that community.

Debe hacerse extensiva la cita " 37 " y debe decir:

This model emphasizes the moment of intervention: before, during, and after the disaster. Responses prioritize two aspects: the consequences of disasters for the community and the actions that may be carried out by the professionals of that community ${ }^{37}$.

Donde dice:

Despite the fact that international experiences in interventions appear so far to be focused on the emergency (event-centered), in recent years the model has began a change towards a transverse-in-time approach, in which the concepts of integrality, promotion, prevention and recovery have become prevalent ${ }^{39}$.

Debe hacerse extensiva la cita " 37 " y debe decir:

Despite the fact that international experiences in interventions appear so far to be focused on the emergency (event-centered), in recent years the model has began a change towards a transverse-in-time approach, in which the concepts of integrality, promotion, prevention and recovery have become prevalent ${ }^{37,39}$.

Donde dice:

In this model, interventions are no longer centered on survival and material recovery, but on integrated levels according to the needs of the affected population, and taking into account the various sectors of action. An important asset is the capacity to bring together the affected community and other social actors into the processes carried out by various institutions to solve the needs of the different levels in a disaster situation. The Sphere Project $^{50}$ is an international initiative based in Geneva that has pioneered the implementation of integral strategies in disaster situations.

Debe hacerse extensiva la cita “ 37 ” y debe decir:

In this model, interventions are no longer centered on survival and material recovery, but on integrated levels according to the needs of the affected population, and taking into account the various sectors of action ${ }^{37}$. An important asset is the capacity to bring together the affected community and other social actors into the processes carried out by various institutions to solve the needs of the different levels in a disaster situation. The Sphere Project ${ }^{50}$ is an international initiative based in Geneva that has pioneered the implementation of integral strategies in disaster situations.

Donde dice:

Models related to this type of intervention put the stress on the empowerment and participation of the affected community in order to integrate it to the assistance activities. The focus is centered on community potential rather than on its deficiencies. Mental health is conceived as having a community component which seeks to integrate promotion, prevention, assistance and recovery, both at family and community levels of the population affected. An instance of this model is a manual and guidebook for mental health developed in Colombia ${ }^{51}$.

Debe hacerse extensiva la cita " 37 " y debe decir:

Following Osorio and Diaz, models related to this type of intervention put the stress on the empowerment and participation of the affected community in order to integrate it to the assistance activities $^{37}$. The focus is centered on community potential rather than on its deficiencies. Mental health is conceived as having a community component which seeks to integrate promotion, prevention, assistance and recovery, both at family and community levels of the population affected ${ }^{37}$. An instance of this model is a manual and guidebook for mental health developed in Colombia ${ }^{51}$.

Donde dice:

Several perspectives for community mental health in these situations were included: interventions based on time, interventions centered on specific types of disaster, interventions by levels or spheres of action, and person-centered interventions.

Debe hacerse extensiva la cita “37" y debe decir:

Several perspectives for community mental health in these situations were included: inter- 
ventions based on time, interventions centered on specific types of disaster ${ }^{37}$, interventions by levels or spheres of action ${ }^{40-49}$, and person-centered interventions ${ }^{37}$.

Donde dice:

The majority of the documents reviewed are addressed to the professionals involved [...]

Debe hacerse extensiva la cita " 37 " y debe decir:

"The majority of the documents reviewed are addressed to the professionals involved" 37 [...]

\section{Referencias}

1. Abeldaño RA, Fernández R. Salud mental en la comunidad en situaciones de desastre. Una revisión de los modelos de abordaje en la comunidad. Cien Saude Colet 2016; 21(2):431-442.

2. Osorio Yepes CD, Diaz Facio Lince VE. Modelos de intervención psicosocial en situaciones de desastre por fenómeno natural. Revista de Psicología de la Universidad de Antioquia 2012; 4(2):65-84. 